\title{
Relation on the Line Governing - The Catholic Church: Based on Polish Situation in the 60s of the Twentieth Century
}

\section{Kamila Krajewska}

Faculty of Social Sciences, Warsaw University of Life Sciences Nowoursynowska 166 Street, 02-787 Warsaw Poland e-mail: kamila.krajewska1987@gmail.com

\section{Marcin Krajewski}

Faculty of Physics, University of Warsaw Hoza 69 Street, 00-681 Warsaw Poland e-mail: marcin.krajewski@fuw.edu.pl

Doi:10.5901/ajis.2013.v2n3p267

\section{Abstract}

In 1966, Poland celebrated its 1000-year anniversary - the Millennium of the Polish Baptism. Millennium preceded the Great Novena, it was celebrated for nine consecutive years (1957-1966). The renewal was made to entrust the Polish people under the providence of the Virgin Mary for the next 1000 years. Millennium of the Polish Baptism was not only a celebration of the Church, but also highlight the strong socio-political overtones. The nature of the Jubilee was especially noticeable in the later manifests itself in the government's policy tightening to the Church, which played a huge role censorship. At the same time, the Communist parliament proclaimed the competing celebration - the Polish State Millennium, designed to celebrate the 1000 year history of the Polish state. The study describes and summarizes the impact of Marxist and Marxist-Leninist doctrine on the development of relations between the state and the Church in Poland. It was analyzed the relations after the World War II with the highlight of the years 1960-1966 when it occurred competitive celebrations of the Polish State Millennium and the Millennium of the Polish Baptism.

Keywords: Marxism, Religion, Catholic Church, Communism, Manipulation, Millennium of the Polish Baptism, Polish State Millennium

\section{Introduction}

Among numerous philosophical currents, social and economical ideas which were created in the past two centuries, only few of them had the real influence on the formation of socio-political situation in the world. However, undeniably one of them was the Marxist doctrine and its subsequent modifications (Leninism, Stalinism). In the beginning of $20^{\text {th }}$ century they determined philosophical and legal systems in many courtiers. Under the influence of those ideas remained some of the countries from Asia, Africa and Central-Eastern Europe, including Poland. The organization of social and industrial life, which were proclaimed under slogans of socialism, universal equality and the secularization of life by Communists, were a kind of transition and very often a cultural shock for communities. One of many aspects where they tried to take over or control partially the impacts was the sacred area. The Communism authorities used the religion to protect or strengthen their power repeatedly. In the moment when the religion became risky it was fought back and its representatives and believers were chicaned. The good example of such kind of behavior was the policy in the Eastern Bloc countries. Among them Poland was the particular place where in the $60 \mathrm{~s}$ of twentieth century there were two special events. In fact they were the opposition celebrations of the same event - the Establishment of the Polish State. In 1957 the authorities of the Catholic Church in Poland initiated the celebration of the Millennium of the Polish Baptism. As the answer the Communist authorities announced the Polish State Millennium in 1958. By announcement of their own jubilee, they wanted to show their suzerainty over the institutions of Church and the secular nature of Poland. It started the 'battle for the number of souls' of catholic citizens (Wilanowski C., 2002).

\section{Religion and Marxism}

In the history, $19^{\text {th }}$ century brought the major changes in both the technological development and transformations of the 
social life. The mass migrations of people to industrial centers and the dynamic growth of the working class led to the creation of new socio-political idea - the scientific Socialism (Marx K., 1970; Kolakowski L., 2009; Tomery S., Townshend J., 2010). In comparison to the earlier views represented by Robert Owen, Henri de Saint-Simon and Charles Fourier (the utopian Socialism), Marx and Engels believed that their doctrine was repeatable and thanks to its it was possible to recognize, describe and predict the results. In the Marx's philosophical considerations there were presented the strong borrowings related to the Hegel philosophy - especially in the aspect of relationship between individuals and their outside world. Under this framework, the materialism was moved to the first place and it became a denial of the idealism i.e. all metaphysics (appeal to the idea). For Marx, it existed only brutal reality. This kind of Marx statement got the name - the dialectical and historical materialism (Tatarkiewicz W., 1988).

By the dialectical materialism, Marx understood only the existence of matter which was continually evolving and constantly adopted the new forms. Everything, what was real, was the form of that matter. It means that one of the matter form was the mental life and consciousness. The historical materialism proclaims that in the reality it exists only matter, whereby the social reality has grown on the material reality which it is the other, higher form than the social reality. The conception of Marx was based on the economy recognizing that it is the basis of the social life. Moreover, philosophy, religion, manners, art remained only spiritual superstructure of the material base. Both terms superstructure and base were the basic terms in the philosophical system which were proclaimed by the Marxism; base - economy as the basis of the social life; superstructure - culture, religion, manners, law i.e. everything which was called the ideology by Marx. The superstructure was created by the ruling class. That class was focused on the social awareness and was responsible for the creation of the ideology in order to obtain material gains at the expense of another man (Anzenbacher A., 1987).

The dialectical and historical materialism is the base for the further considerations of the social justice and the distribution of wealth. However, the significant elements of the Marxism were the essence and meaning of the religion (Thompson J.B., 1990). The considerations about that subject and Marx's understanding of faith was presented in the fragment of introduction to 'Critique of Hegel's Philosophy of Right' published in 1844:

\begin{abstract}
Religion is, indeed, the self-consciousness and self-esteem of man who has either not yet won through to himself, or has already lost himself again. But, man is no abstract being squatting outside the world. Man is the world of man - state, society. This state and this society produce religion, which is an inverted consciousness of the world, because they are an inverted world. Religion is the general theory of this world, its encyclopaedic compendium, its logic in popular form, its spiritual point d'honneur, it enthusiasm, its moral sanction, its solemn complement, and its universal basis of consolation and justification. It is the fantastic realization of the human essence since the human essence has not acquired any true reality. The struggle against religion is, therefore, indirectly the struggle against that world whose spiritual aroma is religion. (Marx, 1970)
\end{abstract}

The similar opinion in terms of the religion essence was included in the subsequent lines of his work where it was underlined that the religion was 'opium of the people' and it was necessary to fight against it constantly (Bochenski J. M., 2006).

The abolition of religion as the illusory happiness of the people is the demand for their real happiness. To call on them to give up their illusions about their condition is to call on them to give up a condition that requires illusions. The criticism of religion is, therefore, in embryo, the criticism of that vale of tears of which religion is the halo. Criticism has plucked the imaginary flowers on the chain not in order that man shall continue to bear that chain without fantasy or consolation, but so that he shall throw off the chain and pluck the living flower. The criticism of religion disillusions man, so that he will think, act, and fashion his reality like a man who has discarded his illusions and regained his senses, so that he will move around himself as his own true Sun. Religion is only the illusory Sun which revolves around man as long as he does not revolve around himself. (Marx K.,1970)

The Marxism position in terms of religion was completely negative. Marx undermined the value and veracity of the religion which was only a product of human or the material-economical base of superstructure in his opinion. He was convinced that the religion and faith were hindering the freedom, therefore he manifested the need of the humanity liberation. According to Marx, the only attitudes of human worth were implacability, struggle and resistance. In the contrast to Marx's point of view, the man of faith was subjected to God thus he was submissive. Marx reduced the idea of God to the ordinary human aspect. In his opinion, God was the product of the human mind. The only positive value of God was that what human brain could attribute. According to Marx, God was living thanks to human mind and He was only kind of the imagination product, therefore He did not have any value (Marx K.,1970). 


\title{
3. Religion and Communism (Marxism-Leninism)
}

The conception of Marx and Engel found a strong electorate among the working class in the beginning of the $20^{\text {th }}$ century. A lot of Marxism assumptions were taken by a faction of the Russian Socialist (later called the Bolshevik Camp) led by Vladimir llyich Ulyanov, known as Vladimir Lenin (Riasanovsky N.V., 2000). Despite the fact that in the beginning of $20^{\text {th }}$ century they had not played a significant role in Russia but two decades later they created the law in one of the largest countries in the world at that time. How strong inspiration for Lenin was the Marxism, it could be seen in his early works. Already in 1905, the leader of Bolshevik tried to convince in the newspaper 'Новая Жизнь' ('New Life') that:

\begin{abstract}
The economic oppression of the workers inevitably calls forth and engenders every kind of political oppression and social humiliation, the coarsening and darkening of the spiritual and moral life of the masses. The workers may secure a greater or lesser degree of political liberty to fight for their economic emancipation, but no amount of liberty will rid them of poverty, unemployment, and oppression until the power of capital is overthrown. Religion is one of the forms of spiritual oppression which everywhere weighs down heavily upon the masses of the people, over burdened by their perpetual work for others, by want and isolation. Impotence of the exploited classes in their struggle against the exploiters just as inevitably gives rise to the belief in a better life after death as impotence of the savage in his battle with nature gives rise to belief in gods, devils, miracles, and the like. Those who toil and live in want all their lives are taught by religion to be submissive and patient while here on earth, and to take comfort in the hope of a heavenly reward. But those who live by the labour of others are taught by religion to practise charity while on earth, thus offering them a very cheap way of justifying their entire existence as exploiters and selling them at a moderate price tickets to well-being in heaven. Religion is opium for the people. Religion is a sort of spiritual booze, in which the slaves of capital drown their human image, their demand for a life more or less worthy of man. (Lenin W., 1985)
\end{abstract}

The main demand of the Socialists was (...) that religion be held a private affair so far as the State is concerned (...). According to the words of Lenin's ideas, it assumed the complete separation between the state and Church institutions. Moreover, he pointed that (...) everyone must be absolutely free to profess any religion he pleases, or no religion whatever, i.e., to be an atheist (...). The differentiation of citizens according to their rights based on the religious beliefs should have been prohibited and additionally the information about belonging or not of citizens to the different ideological options should have been removed. Regarding to the economic correlation between the Church and the state, it was assumed a total subsidization prohibition of ecclesial and religious associations coming from the state funds. Furthermore, all religious associations should have become completely free, independent from the state authorities. The laudable ideals of religious tolerance for citizens did not include the members of the Socialist Parties. As Lenin argued:

So far as the party of the socialist proletariat is concerned, religion is not a private affair. Our Party is an association of class-conscious, advanced fighters for the emancipation of the working class. Such an association cannot and must not be indifferent to lack of class-consciousness, ignorance or obscurantism in the shape of religious beliefs. We demand complete disestablishment of the Church so as to be able to combat the religious fog with purely ideo logical and solely ideological weapons, by means of our press and by word of mouth. But we founded our association, the Russian SocialDemocratic Labour Party, precisely for such a struggle against every religious bamboozling of the workers. And to us the ideological struggle is not a private affair, but the affair of the whole Party, of the whole proletariat. (Lenin W., 1985)

Above declaration was a kind of unwritten requirement addressed to citizens who were forced to declare to become the atheists. All activities, which were opposed to the general rules, were the cause of closure social promotion possibility, persecution, victimization or even death. According to the slogan of the state and Church separation, it was declared the necessity of cleaning(...) of medieval mildew, the proletariat will wage a broad and open struggle for the elimination of economic slavery, the true source of the religious humbugging of mankind (...). (Lenin W., 1985)

\section{The situation of the Church in Poland after 1945}

In 1917 the ideology of Lenin was adopted in the Bolshevik Russia (later the Union of Soviet Socialist Republics) as a result of so-called the October Revolution. After the end of the Second World War the Soviet Union obtained the real impact on the policy in many courtiers. In the result of unwritten division of the world in 1945, there was the formation of two hostile camps - the Western Bloc countries led by the United States of America (USA) and the Eastern Bloc countries led by the Soviet Union (USSR). Among countries under the patronage of Moscow there were the People's Democracy Countries i.e. the People's Republic of Poland, the German Democratic Republic, the Czechoslovak Socialist 
Republic, the People's Republic of Hungary, the Socialist Republic of Romania, the People's Republic of Bulgaria, the Socialist People's Republic of Albania and also outside Europe, the Mongolian People's Republic, the Democratic People's Republic of Korea, the Democratic Republic of Vietnam, the People's Republic of China and the Republic of Cuba etc. Sometimes, historians exclude from above group the following countries: the Socialist Federal Republic of Yugoslavia under the rule of Josip Broz Tito and also the People's Republic of China, the Socialist People's Republic of Albania which were in the ideological conflict with the Soviet leaders (Roszkowski W., 2005).

In 1945 the Communists took the power in Poland. The current leaders were Boleslaw Bierut (Polish: Bolesław Bierutem), Edward Osobka-Morawski (Polish: Edward Osóbka-Morawski) and Wladyslaw Gomulka (Polish: Władysław Gomułka) who created the Provisional Government of National Unity (Polish: Tymczasowy Rząd Jedności Narodowej). In post-war Poland, the demographic and religious structures were changed significantly. In the result of the Holocaust, the German extermination activities and the mass obligatory migration of people, Poland became the ethnically homogeneous country (there were about $97 \%$ Poles). Furthermore, most of Polish citizens declared that they had been the Roman Catholic believers (Szulc and Others., 1947). In the initial phase of acquisition and consolidation of Communists influence, they created the semblances of openness and willingness to cooperate with the Church. the permission to return to school the religion classes, the reactivation of activities of the Catholic University of Lublin (Polish: Katolicki Uniwersytet Lubelski -KUL), the renewal of the 'Caritas' structures (the catholic charity organization), as well as an attempt to establish the contacts with senior hierarchs of the Polish Church. In July 1945, the Communist authorities gave the permission to return of the Polish Primate August Hlond to the country. At the same time, the Church activists and clergy renewed the issue of the Polish Catholic press creating the titles such as 'Sunday' (Polish: 'Niedziela'), 'Warsaw Weekly' (Polish: 'Tygodnik Warszawski') and 'General Weekly' (Polish: 'Tygodnik Powszechny').

The mutual collaboration between the Communists and the Polish Church did not last long time because on 12 September 1945 the Provisional Government of National Unity renounced the Concordat with the Holy See which were signed in 1925. After consolidating their position in the years 1945-1947, they began implementing the Leninist doctrine of church and state separation. In its initial stage, it was mild, however, in the autumn of 1947 the open fight was started and lasted continuously until 1956. At that time, the Communists tried to push the Church into the margins of the public life and after 1950 they tried to penetrate into Its internal structures. The possibility to achieve that was the usage of covert and overt, legal and administrative terror. Furthermore, the Communists discouraged from the Church particularly youths by offering them an opportunity to join to the Union of Polish Youth (Polish: Związek Młodzieży Polskiej) where on Sundays there were organized the activities in the secular way. The Security Service (Polish: Służba Bezpieczeństwa) spied the Catholic environment, hindered the works of the Catholic associations or forbade their activities. Due to the inability of complete religion elimination from schools the Communism authorities hampered the catechization. Moreover, they took the actions to discredit the person of Pope Pius XII because of his alleged attitude during the Second World War - favoring the Nazi Germans. In March 1948 they intensified their position after the letter of Pope to the German bishops where it was written about the possibilities of cancellation of the Potsdam arrangements regarding to the PolishGerman border on the Oder-Neisse line.

In July 1949 there was created the Joint Church-State Committee which was consisted of the Church members represented by bishop Zygmunt Choromanski (Polish: Zygmunt Choromański), bishop Tadeusz Zakrzewski and bishop Michal Klepacz (Polish: Michał Klepacz) and the State authorities represented Wladyslaw Wolski, (Polish: Władysław Wolski), Franciszek Mazur, Edward Ochab. The signed declaration guaranteed to the Church teaching the religion classes at schools, the functioning of the Catholic University of Lublin and Catholic charity organizations and the permission of priests stay in hospitals and prisons. In return, the clergy called for the respect for the authorities, the consolidating peace and the clarifying the structures on the recovered territories (Polish: ziemie odzyskane). In fact, that agreement was not respected. Thanks to that treatments, the Communists proclaimed the apparent negotiations and also the openness for the Church. At the same time, they started to implement the plan of the Ministry of Public Security (Polish: Ministerstwo Bezpieczeństwa Publicznego) to reduce the activity of the Church. In September 1949, there were introduced the regulations which forced the bishops to suspend the activities of all Catholic associations (except for the Cracow Archdiocese) and the organization of religious gatherings (except for the Corpus Christi). It was prohibited to collect the money for charity and also it was introduced the book settlement that allowed to insight into the budgets of the parish. Moreover, the Communist authorities imposed the high taxes on the Church properties, occupied the Church estates on the recovered territories by Poland (after 1945) and strengthened the espionage network among priests.

All treatments of the Communist authorities prompted the Polish Primate Stefan Wyszynski (Polish: Stefan Wyszyński) to sign the agreement on 14 April 1950. In that document, the Church authorities accepted to not interfere in the problem of agricultural collectivization, condemned the symptoms of 'Polish banditry' (the military actions organized 
by the underground independence organizations) and also undertook to persuade the Vatican to establish the permanent dioceses on the recovered territories by Poland. In the answer, the State authorities undertook to ensure the freedom of religious education at schools, to preserve the existing Catholic schools and to authorize the issue of the Catholic press. The Communist authorities did not keep the established postulates and in September 1952 they prohibited completely to teach any religion and they closed all monastic schools. At the same year, it was arrested the rector of the Catholic University of Lublin Fr. prof. Antoni Slodkowski (Polish: Antoni Słodkowski) and two years later there were liquidated the theological faculties at two the most important universities in Poland: at the University of Warsaw and at the Jagiellonian University.

On 9 February 1953, the Communist authorities issued a decree on the filling of the clergy positions and since that moment, they decided about it. That act included both vicars and bishops. The reaction of the Church was expressed in the famous letter to the current authorities called 'Non possumus' published on 6 May 1953. That letter presented the strong opposition of the Church against the Communist authority decree. Furthermore, it contained the information that it could have been better not to fill in the Church positions than to put up with the people substituted by the State authorities. The Church leaders announced the threats of excommunication to those who would have dared to accept the nominations without the permission of the Church authorities. On 23 September 1953, the Politburo of the Polish United Workers' Party (abbreviation - the Political Bureau; Polish Biuro Polityczne Komitetu Centralnego Polskiej Zjednoczonej Partii Robotniczej) took a decision to intern the Polish Primate Wyszynski. It was happened at night on 25 September. That time, he was secretly arrested and deported from Warsaw. The Primate was detained in the solitary confinement until autumn 1955. During the absence of the Primate, the Church in Poland was led by bishops Michal Klepacz, Zygmunt Chromanski and Teodor Bensch. That circumstance 'broke down' the spirit of the Church authorities who issued the conciliatory message for the Communists on 28 September 1953. They obliged to respect the agreement from April 1950. The state of hostility continued until 1956 when Wladysław Gomulka became the function of the First Secretary of the Central Committee of the Polish United Workers' Party (Polish: I sekretarz Komitetu Centralnego Polskiej Zjednoczonej Partii Robotniczej) (Noskowska A., 2009; Dudek A.,2006; Zaryn J., 2004).

\section{Millennium of the Polish Baptism vs. the Polish State Millennium}

In 1966 there were two important events from the point of view of the Polish history - conventionally adopted the Millennium of the Establishment of the Polish State and the actual anniversary of the Prince Mieszko I baptism. Both jubilees could have become the opportunity to unify the whole nation during the celebration of the great feast, however, in that moment the political situation made that they were celebrated separately. Moreover, they were organized as the opposing feasts inspired by the Communist authorities (Noszczak B., 2007).

A turning point towards the celebration of the Millennium of the Polish Baptism became the socio-political changes which took the place from the end of 1954. At that time, due to the weakening of the party-state structures the Church gained the opportunity to develop the wider activity that was free from the control of the Communist regime.

According to the plans of the celebration of the Baptism Millennium, the first initial point of that anniversary was the Vows of Nation which took the place on 26 August 1956 at the Jasna Gora Sanctuary in Czestochowa (Polish: Jasna Góra w Częstochowie). During that ceremony the crowd of pilgrims, who were gathered at the foot of the Czestochowa Monastery, said 'The Queen of the Polish, we promise!' (in Poland, that title belongs to Virgin Mary - Mother of God). Regarding to the security apparatus of the Communist authorities, from 600 to 700 thousands participants took part in the Church ceremonial at Jasna Gora but the Church data was estimated as high as nearly one million participants. In fact, the vows was not only filed at Jasna Gora but in all parishes in Poland where all faithful were able to participate in the religious devotions.

The celebrations of the renewal of vows were not only an unprecedented manifestation of religious beliefs in the countries of so-called Eastern Bloc but also they constituted a remarkable expression of the unity of the faithful with the interned Primate Wyszynski, expanded to request his release. This particular manifestation impressed not only the hierarchs but also the authorities and it revealed not only the strength of attachment the majority of the population to the faith, to the Church and to isolated in Komancza (Polish: Komańcza) the Cardinal Stefan Wyszynski but also the failure of religious policy in the Communist state. (Noszczak B., 2007)

The next chapter in the history of the Catholic Church in the Polish People's Republic was opened by the implementation of socio-political changes related to the turn of the October 1956. At that time, the highly repressive religious policy of the Communist authorities was eased definitely. Under influence of the post-October thaw, the team of 
the new first secretary of the Central Committee of the Polish United Workers' Party (Wladyslaw Gomulka) released the Primate Stefan Wyszynski who came back Warsaw and he started afresh the Primate reign. The Church used the remarkable improvement in the relations with Communist authorities to release permanently from the dictates of them. As a part of Its activities, the Church launched the wide-ranging campaign for the renewal of religious and social life in the country. According to the plan, on 3 May 1957 the Primate Wyszynski celebrated the Mass at Jasna Gora. On the one hand, it was the closing ceremony of the Year of the Queen of the Polish and on the other hand it was a solemn announcement of the Great Novena of the Nation before the Millennium of the Polish Baptism which was the next stage of preparation for Polish citizens for the great Jubilee of their Christianity. (Noszczak B., 2007)

The program of the Millennium celebration had essentially the pastoral-religious character. It was directed towards 'the man' and the future. Moreover, it was assumed the battle against the spiritual and mental breakdown of the nation mainly caused by the traumatic experiences of the World War II and the policy of the Communist regime. To bring out the society from the religious-moral stagnation the Episcopate presented a concise synthesis of intended purpose which was to be implemented under the program of the Great Novena as a specific rechristianization of Poles. The first step on the way to that moral-religious renewal was a pursuit to increase the awareness of the fact that Poles are the Christian nation. The second one - treatment and deepen their religious life. The third and the last one, it was related to the conforming of the nation to the apostolic revelation of the Christian aspect and also the removal of the secularization and the deformation of Christianity features caused by the sin. (Noszczak B., 2007; Wilanowski C. (ed.), 2002)

Even though the primary and declared mission of the Millennium celebrations was to be the spiritual renewal, it also brought a strong accent of political manifestation which was aimed to show the strength of the Church in the face of Communist authorities and also to show the attachment of society to the Church institution. The mobilization action of faithful was understood as an expression of their attachment not only to the institution which carried out the spiritual ministry but also to the center of the Communist system opposition. Although that specific-political aspect of the Millennium was not demonstrated directly, it was clear for both the authorities and the society.

Around 1958, the new Communist authorities began again to limit the socio-religious impact of the Church. Because of that, the Great Novena (the most important missionary program of the Church activity) became once again the target of propaganda attacks. The chicanes and obstacles adopted a character of administrative actions which were aimed not only in the base of above mentioned program but first of all in the Church institution. Also for the same reason, in 1960 the Communist government launched its own standalone program of the Polish State Millennium which was the competitive and kind of secular alternative to the celebrations of the Millennium of the Polish Baptism.

In years 1958-1965, most of assumptions of the Great Novena program were realized, however, the Church and believers had to face with the significant resistance from the side of authorities. Despite some incidents, the signs of conflict over the Millennium celebrations were not very seen and that relation could be described as a 'silent war'. But the conflict over the celebrations continued to grow with each passing month and the closer the 1966 it became more visible and rough. It started on 18 November 1965 when it was issued 'The message of the Polish bishops to their German brethren in Christ's pastoral office' which was used as an argument for the Communist authorities to intensify the antiChurch campaign in the Year of Jubilee and it initiated so-called the 'battle for the number of souls'. Furthermore, the document, which was mentioned above, did not have only a deep religious significance but also in a certain sense the political overtone. On the one hand, it was related to the anniversary of the Millennium of the Polish Baptism and on the other hand it touched the issue of relationship between the Polish People's Republic and the Federal Republic of Germany. In the message the hierarchs presented the millennial history of Poland with particular reference to the neighborhood with Germans. The most important place in that historical analysis was occupied by the most recent acts, in particular including the events related to the Second World War and its painful consequences for both nations. The most important of the message was that the Polish bishops declared the forgiveness of the crimes committed by Germans during the war, at the same time urging them to excuse sins committed against Germans by Poles. From today's perspective, it is seen that those unusual and Christian gesture of reconciliation and humility, which was surprising to most commentators in 1965, began to bring the expected results after years. (Noszczak B., 2007)

The ceremony at Jasna Gora did not close the Millennium celebrations in the country. They lasted until the end of 1966 despite larger or smaller obstructions from the authorities. Until July 1967 they were organized the 'unaccomplished' Millennium celebrations in Sosnowiec, Lodz (Polish: Łódź), Kamien Pomorski (Polish: Kamień Pomorski) i Kolobrzeg (Polish: Kołobrzeg). 


\section{Conclusions}

The Jubilee of the Polish Statehood became a great impulse of organized spiritual action of the Church. That event was torpedoed by the Communist authorities but it did not bring the expected results which had been predicted by the team of Wladyslaw Gomulka. Although the main assumption of the Communists was the formation of materialistic attitude to life in the citizens, the believers massively opposed to such an approach and they expressed their religious feelings. Furthermore, it was significant for the situation of the Church in Poland that after more than 20 years of secularization and administrative control of the Church institutions, the Church was able to organize the Millennium Celebrations on such a large scale (Noszczak B., 2007). The celebrations of the Polish Baptism contributed not only to strengthen the Catholicism among the Polish Nation but also they became the political expression of the union between the faithful and the Church. On the other hand, that attitude was also a kind of distrust sign against the Communist authorities and the general idea of secularization. The important issue remained that during the celebrations of the Polish Baptism Jubilee the part of the society stayed in the relationship with the Polish People's Republic. Therefore, the Polish society was divided into two groups. One of them was loyal to the Church and the second one faithful to the Communist party. People, who belonged to the second group, identified themselves as the atheists or the enemies of the Church. Nevertheless, the Polish situation in the $60 \mathrm{~s}$ of $20^{\text {th }}$ century was not a precedent but it was a tangible evidence of mutual antipathy, sometimes even hostility between the Communists and the Church. In fact, the idea of Lenin's atheism and total secularization of society life was met with the strong public resistance in the Polish People's Republic.

\section{References}

Anzenbacher A. (2008). Wprowadzenie do filozofii. Cracow. WAM Publishers.

Bochenski J. M. (2006). Marksizm - Leninizm Nauka czy wiara?. Komorow. Antyk Publishers.

Dudek A. (2006). Komunisci i kosciol w Polsce (1945-1989). Cracow. ZNAK Publishers.

Kolakowski L. (1978). Main current of Marxism. Oxford. Clarendon Press

Lenin V. I. (1965). Socialism and Religion. (in.) Lenin Collected Works. Moscow. Progress Publishers.

Marecki J. (2011). Represje wobec kosciola w krajach bloku wschodniego. Cracow. WAM Publishers.

Marx K. (1970). Critique of Hegel's Philosophy of Right. Oxford. Oxford University Press.

Noskowska A. Stosunki PRL-kościół katolicki w latach 1945-1956 http://historia.org.pl/2009/06/16/stosunki-prl-kosciol-katolicki-w-latach1945-1956/

Noszczak B. (2010). Obchody Milenium chrztu Polski w latach 1956-1966/1967. http://www.klubgeneralagrota.pl/portal/kg/38/600 IObchody_Milenium_chrztu_Polski_w_latach_195619661967.html.

Pospielovsky D. (1984) The Russian Church under the Soviet regime 1917-1982. Crestwood-New York, St. Vladimir's Seminary Press.

Roszkowski W. (2005). Polwiecze. Obraz historii swiata po 1945 roku. Warsaw. Polish Scientific Publishers PWN.

Tatarkiewicz W. (1988). Historia filozofii, Warsaw, Polish Scientific Publishers PWN.

Tormey S., Townsend J. (2006). Key Thinkers from Critical Theory to Post-Marxism. UK. Sage Publications.

Thompson J. B. (1990). Ideology and modern culture: critical social theory in the era of mass communication. Stanford. Stanford University Press.

Riasanovsky, N. V. (2000). A History of Russia. Oxford. Oxford University Press.

Wilanowski C. (ed). (2002). Millennium polskie : walka o rzad dusz. Warsaw, PAX Publishers.

Zaryn J. (2004). Kościół w PRL, Warsaw. The Institute of National Remembrance Publishers. 
